DOI: https://doi.org/10.24297/jssr.v14i0.8384

\title{
The Determinants Impacts on The Profitability of The Vietnamese Commercial Banks in The Periods of 2010 To 2017
}

\author{
Khiem Dieu Truong \\ Hcm International University \\ tdkhiem@hcmiu.edu.vn
}

\begin{abstract}
The study location only resides in Vietnam with the focused group of all 28 commercial banks in Vietnam. The main source of statistics for this testing will come and be collected directly from the financial statement all financial institutions for 2010 and 2017. In term of panel data analysis, this should require for the Hausman test in term of differentiation between fixed effects model and random effects model (Sheytanova, 2015). This should ensure for the accuracy of the test result in term of the hypothesis testing's power and size as well as in term of obtaining consistent result.

The result will conducted in term of for each dependent variables and one for collaboration of all dependent variables. For the purpose of the T-test results, we will have to look at the t-statistic, t-distribution and degrees of freedom to determine a $p$ value (probability) which can also be utilized to determine whether the population means differ. The result expect to have the size of the bank indicating no influence but all other dependent variables shall have impacts on the profitability of the bank in term of financial performance.
\end{abstract}

Keywords: Profitability, commercial banks.

\section{Introduction}

Under the term of financial performance and transformation of the Vietnam's market, there should have been witnessing various changes and undergoing business transformation of bank in Vietnam. Furthermore, the new implementation of Basel II and increasing flow of Foreign Direct Investment (FDI) in the market shall raise the question on the determinants and components of operational impacts of commercial bank in Vietnam (Hoa and Lin, 2014). Therefore, from overview perspective, the review will be divided into the two categories of factors of internal and external process. These two factors will be assessed and specified to industry and macroeconomic factors as external contribution and bank-specific as internal contribution.

There has not been a review and assessment of commercial banks' data in Vietnam in term of determined factors to the overview of business's profitability. Therefore, the literature review of this thesis will be indicated in the role of review of core concepts and relevant theories over the topic of research problem.

As indicated above, the research question will be "how can boost the profitability of commercial banks in Vietnam based on the study of determinants of banks' profitability". The objectives will be to identify and allocate the top relevant determinants for all 28 commercial banks in Vietnam based on the support of data analysis and data testing. The expected outcomes will be consistent with empirical findings of the data analysis along with the assistance and review of core concepts and theories regarding the nature of developing market as Vietnam. These all factors should have both positive and negative impacts in the business performance of all sample selected banks.

It is obvious that the bank plays an important in the economic in which the bank is the intermediate to connect the entities in the economic. The entities are supported in the financial aspects to operate the business smoothly. In the developing countries, the importance of the bank is significant in the development of the entire economic. 
The failure of the bank system will result in the financial crisis and economic crisis. Therefore, the bank system is considered as the back bone of the economic. The Governments in the world pay much attention in increasing the profitability of the bank system. The Vietnamese Government is not excepted.

The aim of the study is to clarify the factors influence on the profitability of the Vietnamese commercial banks in the period of 2010 to 2017. Therefore, the study will answer some questions below: Question 1: Which factors impact on the profitability of the bank in Vietnam in the period of 2010 to 2017 ?

Question 2: How significant impact of the factors on the profitability of the bank in Vietnam in the period of 2010 to 2017 ?

Question 3: Form the practical result, what is the good policies for Vietnamese Government to improve the performance of the Vietnamese bank system?

\section{Materials and Methods}

\section{Efficient Structure Theory:}

In the ES theory, the bank can earn the higher profit since they are more efficient than others. In the ES theory, there are two different approaches which are the X- efficiency and the Scale - efficiency. In the X- efficiency, the firms are more efficient which will create more profit because of the low cost. The bank will benefit from the larger marker concentration. The larger banks will gain more market shares which will create more profit (Athanasoglou et al, 2006).

\section{The Balance Portfolio Theory:}

The portfolio is considered as the related theory which is the important roles in the performance of the bank (Nzongang and Atemnkeng, 2006). According to the Portfolio theory, the high asset diversification will create the high optimum holding of asset which will create the high profit for the bank.

There are the internal and external determinants which will impact on the profit of the bank. The internal factors are inside the firm which can be controlled by the bank such as balance sheet, the bad debt rate, bank size and the capital structure of the bank (Demirguc-Kunt and Huizinga, 2000).

The external factors are outside the bank in which the bank cannot control these factors. The external factors are inflation rate, economic growth etc.. which factors impact on the operating and the performance of the bank (Barajas et al., 1999). The internal factors are managed by the bank in which the managers are trying to create the maximum profit for the bank. Besides, the manager also wants to optimize the cost of the bank (Bikker and $\mathrm{Hu}$, 2002). Therefore, the intension of the managers will direct impact to the internal factors such as bad debt rate. It is argued that the managers want to make more loans to the customers. The managers reduce some credit criteria assessing to attract the customers (Goddard et al., 2004),. The action can increase the sales revenue in the short term. However, the long term profit will be negatively impacted by the future bad debt. The managers also want to increase the profit and revenue through increasing the size and capital structure. Regarding to the external factors, all firms will be impacted by the external factors such as economic, inflation rate of the country. The develop of the country will support to create the profit for the firm and the bank. However, the high inflation will reduce the profit of the bank because of the increasing of the price (Miller and Noulas, 1997).

The research is the Ho and Saunders, 1981 is the base for the next researches about the performances of the bank. Previously, there are two schools to explain for the performance of the bank. The first school referred to hypothesis of the self - insurance. The second schools refer to the maximizing the profit of the bank. Regarding to the first school, the bank also balance the assets and liabilities. This will overcome the risk of the imbalance of loans and the deposit of the customers. Therefore, this school point out that the fluctuation of the interest 
rate as the main factor impacting on the performance of the bank. However, this model does not consider as the activities of the bank is to maximize the profit. In the second school, the purpose of the bank is to maximize the profit. With the given hypothesis, Pyle, 1971 presented the all conditions for the existing of the intermediate financial institutions. It is stated that there is the no connection among the deposit interest rate and loan interest rate. There is the variance among the deposit interest rate and loan interest rate in which the loan interest rate is higher than deposit interest rate. However, this school does not consider about the other factors impacting on the performance of the bank. The research model of Ho and Saunders, 1981 presented the perfect model to reflect the performance of the bank. The model presented the factors of the interest rate, inflation rate, size, capital ratios, credit risk, economic growth, M\&A and province ratio.

For the purpose of this thesis, the empirical model will be as below:

$$
\mathrm{Y}=\beta 0+\beta 1 \mathrm{X} 1 \text { (internal factor) }+\beta 2 \mathrm{X} 2 \text { (Macro factor) }+\beta 3 \mathrm{X} 3(\mathrm{M} \& A)+\varepsilon
$$

From this selection of model, the variables as below:

\begin{tabular}{|l|l|}
\hline Variables & Description \\
\hline ROA & Net income/Average Asset \\
\hline Bad Debt & Non-perfoming Loan (NPL) \\
\hline Bank Size & Log of total assets \\
\hline Capital adequacy & Equity / total assets \\
\hline Scale & The number of provinces / total provinces \\
\hline M\&A & Banks with merger factors in research period time (dummy variable) \\
\hline Inflation & GDP deflator (\%) \\
\hline Economic growth & GDP per capital growth (\%) \\
\hline
\end{tabular}

Models: Panel data.

Estimation method: OLS, Fixed effect, Random effect, Generalized least square.

Regression diagnostic: multicollinearity, heteroscedasticity, unit root test, correlation.

The selected subjects are Vietnamese commercial banks. In this research phase, the banking sector in Vietnam has a total of 28 domestic commercial banks. In addition, in order to ensure that banks are selected as research subjects with similar data within the same time frame, banks need to ensure that they meet the conditions Specifically, each selected bank must have a financial statement by the end of 2017 . The second condition is that the data of the target banks must be accessible during the period from January 1, 2010 to December 31,2017 .

Data sources used in this study are secondary sources, including annual reports from banks, the State Bank of Vietnam, Vietnam Bank Statistics, and the World Bank. In addition, the obtained data on the specific factors affecting the bank's profitability are calculated manually from the individual financial statements of the banks. 


\section{Results and Discussion}

\section{Results:}

The rate of the relations ranged from -1 to 1 and the nearer the outcomes to 1 or -1 , the solider the correlation (Taylor, 2005). In addition, Kennedy (2008) displays that multi-collinearity happens in the scenario of correlation being larger than 0.80 or lesser than -0.80 . In Table, this is vibrant of indication for no pair of variables that establishes a correlation of value being bigger than 0.80 or lesser than -0.80 , so no multi-collinearity happens, so none of variables are excluded from the regression model. The peak correlation coefficient is - 0.33 between adequacy and bank size.

\begin{tabular}{|c|c|c|c|c|c|c|}
\hline Source & SS & $d f$ & MS & Number of obs & $=$ & 211 \\
\hline Model & 28.9018585 & 7 & 4.12883693 & Prob $>F$ & $=$ & 0.0000 \\
\hline Residual & 48.0603649 & 203 & .236750566 & R-squared & $=$ & 0.3755 \\
\hline Total & 76.9622234 & 210 & .366486778 & Root MSE & $=$ & .48657 \\
\hline
\end{tabular}

\begin{tabular}{r|rrrrrr}
\hline ROA & Coef. & Std. Err. & $t$ & P $>|t|$ & [95\% Conf. Interval] \\
\hline NPL & -.0774659 & .0236815 & -3.27 & 0.001 & -.1241592 & -.0307726 \\
size & .2804091 & .1749777 & 1.60 & 0.111 & -.0645977 & .6254159 \\
adequacy & $\mathbf{8 . 0 0 5 2 5 6}$ & 1.344477 & 5.95 & 0.000 & $\mathbf{5 . 3 5 4 3 2 6}$ & 10.65619 \\
GDP_growth & .1431845 & .0697568 & 2.05 & 0.041 & .0056438 & .2807252 \\
inflation & .04343 & .0071026 & 6.11 & 0.000 & .0294258 & .0574343 \\
ratio_provinces_cities & .2892127 & .2604341 & 1.11 & 0.268 & -.2242901 & .8027156 \\
MA & -.1902996 & .0907077 & -2.10 & 0.037 & -.3691497 & -.0114495 \\
_cons & -3.369974 & 1.476086 & -2.28 & 0.023 & -6.280401 & -.4595469 \\
\hline
\end{tabular}

Figure 1: The linear regression model

Basing on the result of OLS regression model, it is indicated that there low value of $\mathrm{R}$ and $\mathrm{R}$ squared which are $37 \%$ and $35 \%$ respectively. Therefore, in the OLS model, the explainable variables explain $35 \%$ the value of the ROA, profitability of the bank. Therefore, the value of OLS model is undesirable.

\begin{tabular}{|c|c|c|}
\hline variable & VIF & $1 / V I F$ \\
\hline $\begin{array}{r}\text { size } \\
\text { ratio prov s } \\
\text { adequacy } \\
\text { GDP_growth } \\
\text { inflation } \\
\text { NPL } \\
\text { MA }\end{array}$ & $\begin{array}{l}6.55 \\
3.84 \\
2.61 \\
1.18 \\
1.13 \\
1.12 \\
1.10\end{array}$ & $\begin{array}{l}0.152565 \\
0.260188 \\
0.382776 \\
0.844221 \\
0.882671 \\
0.891692 \\
0.905096\end{array}$ \\
\hline Mean VIf & & \\
\hline
\end{tabular}

Figure 2: The collinearity result of the variables

In the value of VIF, in case the VIF value is more than 2, there is high probability of the multicollinearity. In case the VIF value is more than 10, there is the multicollinearity of the variables. The VIF is less than 2 , there is no multicollinearity. In the table, the value of VIF is less than 2, hence, there is no multicollinearity among the variables. 
However, the value of the R and R squared of the OLS model is not desirable. Therefore, the author must conduct another model to provide the desirable results.

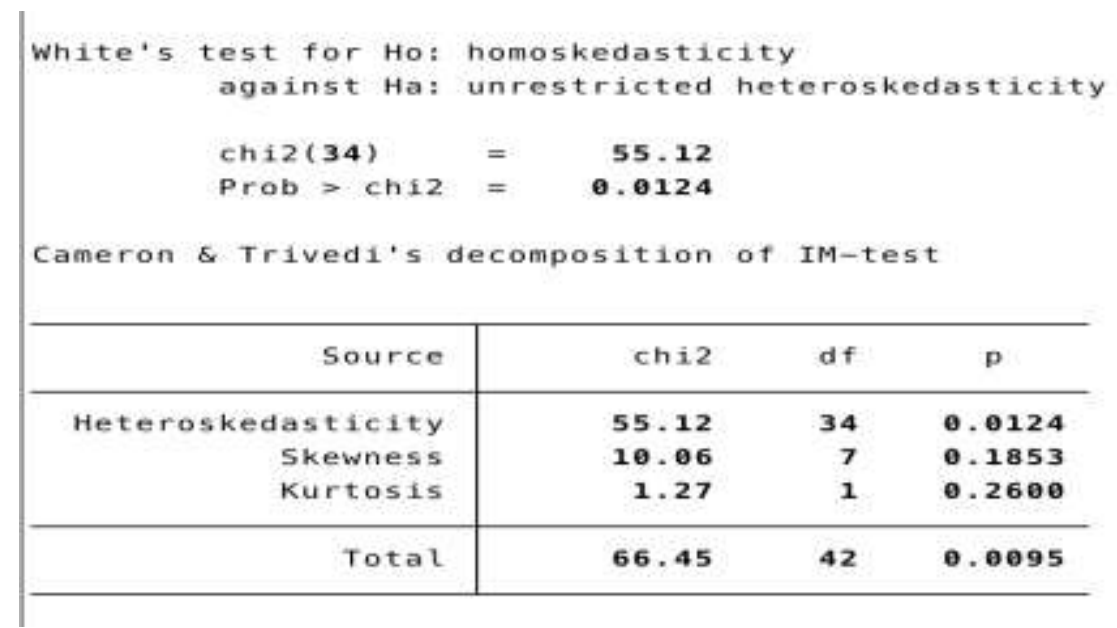

Figure 3: The homoscedasticity test

The White test is conducted to test the homoscedasticity of the variables. The $p$ value of White test is 0.0124 which is less than 0.05 . Therefore, the null hypothesis is no accepted, there is the no homoscedasticity among the variables.

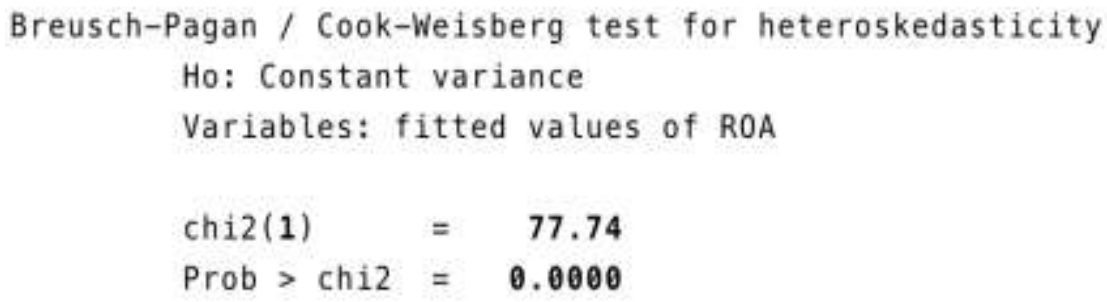

Figure 4: the Breusch - Pagan test

In the test of Breusch - Pagan, the $p$ value of the testing is 0.000 which indicates for being less than 0.05 . Therefore, the null hypothesis is rejected, the alternative hypothesis is accepted which is indicated that variables are fitted values of ROA.

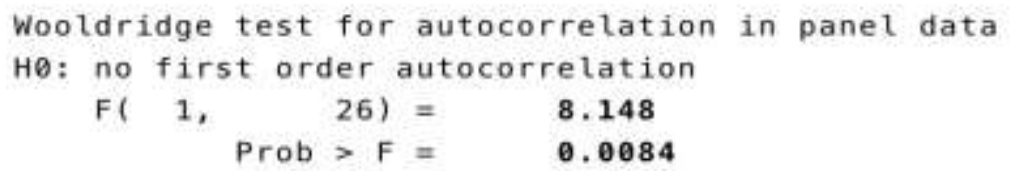

Figure 5: The Wooldridge test

In the test of Wooldridge test for the autocorrelation in the panel data, the $p$ value of the test is 0.0084 which is less than 0.05 . Therefore, the null hypothesis is rejected in which the no first order autocorrelation is rejected.

The fixed or random effect models are employed. 


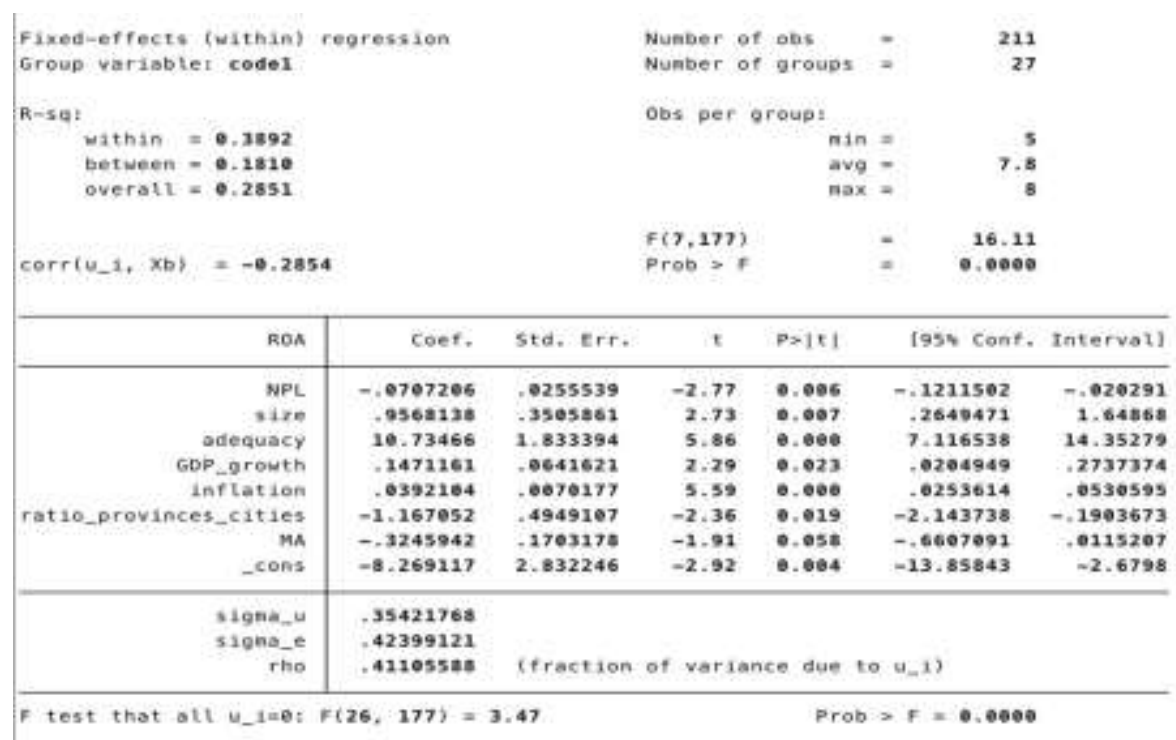

Figure 6: The fixed effect model result

\begin{tabular}{|c|c|c|c|c|c|c|c|c|}
\hline \multirow{2}{*}{\multicolumn{3}{|c|}{$\begin{array}{l}\text { Randon-effects GLS regressian } \\
\text { Group variable; code1 }\end{array}$}} & \multicolumn{3}{|c|}{ Nunber of obs } & \multicolumn{3}{|c|}{211} \\
\hline & & & Nunber $\Rightarrow$ & grou & & $=$ & 27 & \\
\hline \multicolumn{3}{|l|}{$R-34 t$} & \multicolumn{6}{|c|}{ Obs per groupi } \\
\hline within $=0.3741$ & & & & & nin & $=$ & 5 & \\
\hline between $=\mathbf{0 . 3 7 8 6}$ & & & & & ovg & - & 7.6 & \\
\hline \multirow{3}{*}{\multicolumn{3}{|c|}{ overalt $=0.3618$}} & & & $\max$ & * & 8 & \\
\hline & & & \multirow{2}{*}{\multicolumn{3}{|c|}{$\begin{array}{l}\text { Waid chi2(n) } \\
\text { Prob }>\text { chi2 }\end{array}$}} & $\cdot$ & \multirow{2}{*}{\multicolumn{2}{|c|}{$\begin{array}{l}120.16 \\
0.0000\end{array}$}} \\
\hline & & & & & & - & & \\
\hline $\operatorname{mon}$ & Cont. & Std. Err. & $x$ & $p \times 12$ & & [95: & Cenf. & Intervat1 \\
\hline NPL & -.8724424 & .0239365 & $-3,03$ & 0.00 & & -.119 & 9318 & -.0255668 \\
\hline size & .5752721 & .2224703 & 2.59 & 0.01 & & .1392 & 2383 & 1.011306 \\
\hline sdequscy & 9.347526 & 1.514386 & 6.17 & 0.00 & & 6.379 & 9393 & 12.31567 \\
\hline GDP_grouth & .147284 & - 6630985 & 2.33 & 0.02 & & 0236 & 6289 & .270939 \\
\hline inflation & 0416138 & .006432 & 6,47 & 0.00 & & .0290 & 0072 & .0542203 \\
\hline ratio_proxinces_cities & -2028759 & .336887 & $-8.6 \theta$ & 0.54 & & -.8631 & 1623 &, 4574105 \\
\hline MA & -.2781323 & .1134744 & -2.45 & $\theta .01$ & & -.580 & 0538 &.,- 0557265 \\
\hline -cons & -5.613618 & 1.805687 & -3.11 & 0.00 & & -9.151 & 1523 & -2.075713 \\
\hline signa $=$ & -23419151 & & & & & & & \\
\hline signa_e & -42393121 & & & & & & & \\
\hline the & .23376958 & Cfraction & of varia & ce du & to to $30-30$ & 0,13 & & \\
\hline
\end{tabular}

Figure 7: The random effect model result 
Haumans test:

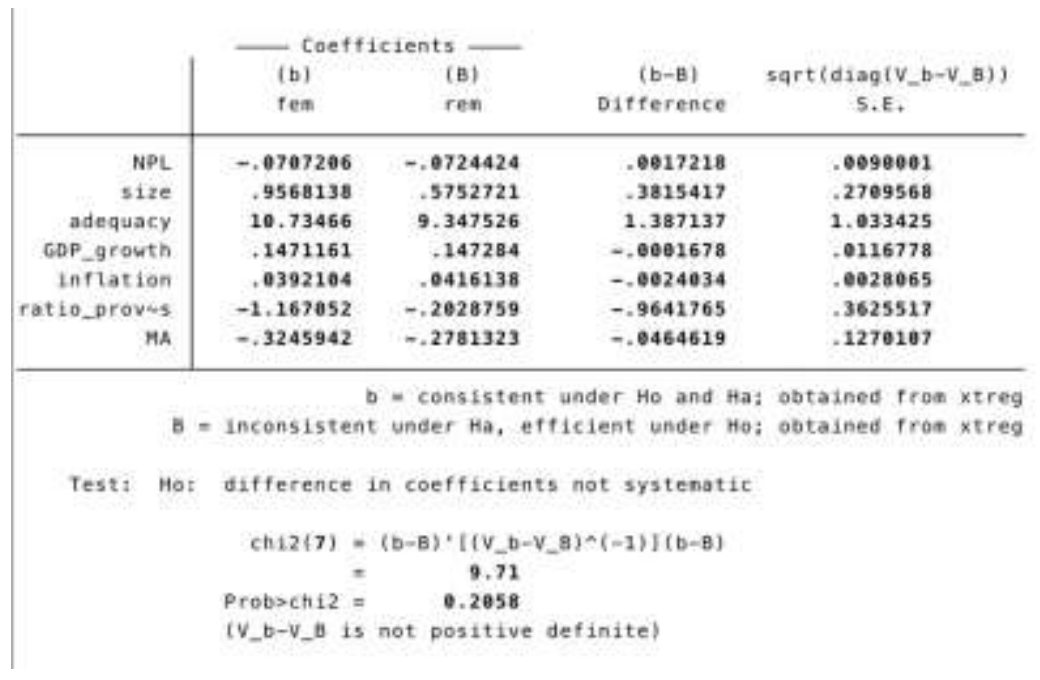

Figure 8: The Hausman test

In the result of the Hausman test, the $p$ value of the Hausman test is 0.205 which is higher than 0.05 . Consequently, the null hypothesis is accepted which means the random effect model is appropriate for the model.

\begin{tabular}{|c|c|c|c|c|c|c|c|c|}
\hline \multirow{2}{*}{\multicolumn{3}{|c|}{$\begin{array}{l}\text { Randoa-effects GLS regressing } \\
\text { Grous variable; codel }\end{array}$}} & \multicolumn{3}{|c|}{ Nusber of obs. } & \multicolumn{3}{|c|}{221} \\
\hline & & & Nunber $\Rightarrow$ & grout & $=$ & & 27 & \\
\hline \multicolumn{3}{|l|}{$R-3 q i$} & \multicolumn{6}{|c|}{ Obs per groupt } \\
\hline within $=0.3741$ & & & \multicolumn{3}{|c|}{$\min =$} & \multicolumn{3}{|c|}{5} \\
\hline between $=0.3786$ & & & \multicolumn{3}{|c|}{ ovg } & \multicolumn{3}{|c|}{7.8} \\
\hline overatt = 0.3618 & & & & & 1. & & $\mathrm{~s}$ & \\
\hline \multirow{2}{*}{\multicolumn{2}{|c|}{$\operatorname{corr}\left(u_{-}-1, x\right)=0$ (assuaed) }} & \multirow{2}{*}{\multicolumn{3}{|c|}{$\begin{array}{l}\text { Waid chi2 (n) } \\
\text { Prob }>\text { chi2 }\end{array}$}} & \multirow{2}{*}{\multicolumn{4}{|c|}{$\begin{array}{l}120.16 \\
0.0000\end{array}$}} \\
\hline & & & & & $\cdot$ & & & \\
\hline ana & Conf. & Std. Eer. & $z$ & $P * \mid z$ & & [9st & Cenf. & Interval] \\
\hline NPL & -0724424 & .0239165 & $-3,63$ & 0.002 & &,- 119 & 19318 & -.0255668 \\
\hline size & .5752721 & .2224703 & 2.59 & 0.018 & &, 1392 & 92383 & 1.011306 \\
\hline sdequscy & 9.347526 & 1.514386 & 6.17 & 0.000 & & 6.379 & 79383 & 12.31567 \\
\hline GDP_growth & .147284 & -663e9es & 2.33 & 0.020 & & 0236 & 36289 & .270939 \\
\hline inflation & .0416138 & .006432 & 6,47 & 0.000 & & .0290 & 90072 &, 0542203 \\
\hline ratio_provinces_cities &,- 2028759 & .336887 & $-8.6 \theta$ & 0.547 & & -.8631 & 31623 & .4574105 \\
\hline MA & -.2781323 & .1134744 & -2.45 & 0.01 & & -.580 & 90538 &.,- 0557265 \\
\hline -cons & -5.613618 & 1.805687 & -3.11 & 0.002 & & -9.151 & 51523 & -2.675713 \\
\hline signa_u & -23419151 & & & & & & & \\
\hline signa_e & -42393121 & & & & & & & \\
\hline the & .23376958 & (fraction & of variar & ice sus & & Q_-13 & & \\
\hline
\end{tabular}

Figure 9: The random effect model result 


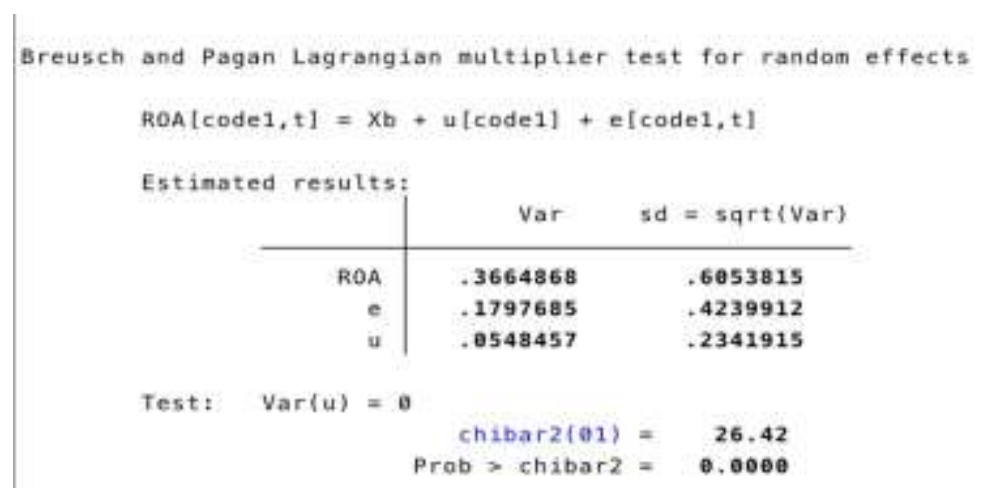

Figure 10: The Breusch and Pagan test result

Basing on value of Breusch and Pagan test, the $p$ value of the test is 0.000 which is less than 0.05 . Therefore, the null hypothesis is rejected, the alternative hypothesis is accepted. It is indicated that the model of the random is appropriate.

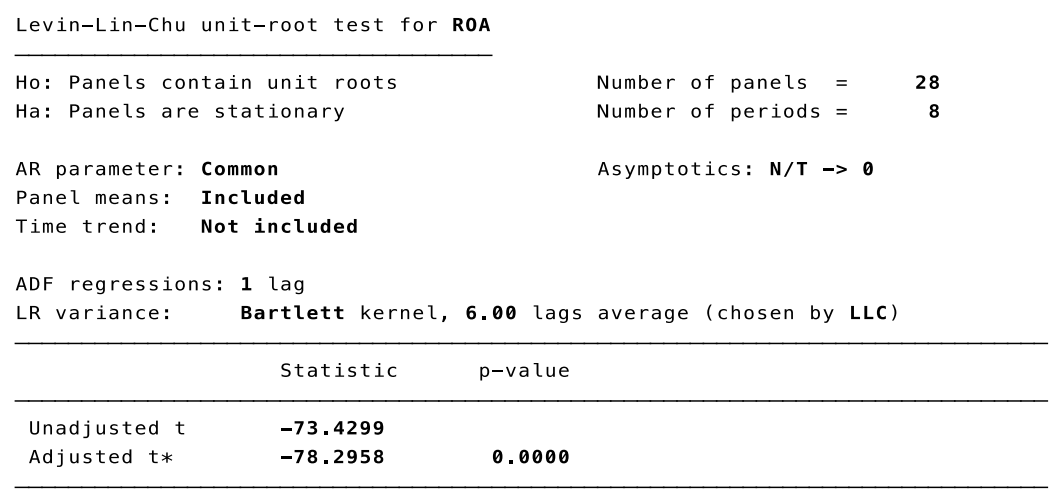

Figure 11: The result of unit root test

The $p$ value of the unit root test is 0.000 which is indicated the panel data is stationary.

\begin{tabular}{|c|c|c|}
\hline Ho: All panels are stationary & Number of panels $=$ & 28 \\
\hline Ha: Some panels contain unit roots & Number of periods $=$ & 8 \\
\hline \multirow[t]{2}{*}{$\begin{array}{l}\text { Time trend: } \\
\text { Heteroskedasticity: } \\
\text { LR variance: }\end{array}$} & Asymptotics: $\mathbf{T}, \mathrm{N}$ & $\begin{array}{l}\text {-> Infinity } \\
\text { sequentially }\end{array}$ \\
\hline & $p$-value & \\
\hline 9.7892 & 0.0000 & \\
\hline
\end{tabular}

Figure 12: The result of stationary test

The $p$ value of the stationary test is 0.000 which is indicated that some panels contain the unit roots. Therefore, the Generalized least squares model to issue the expectable value. 


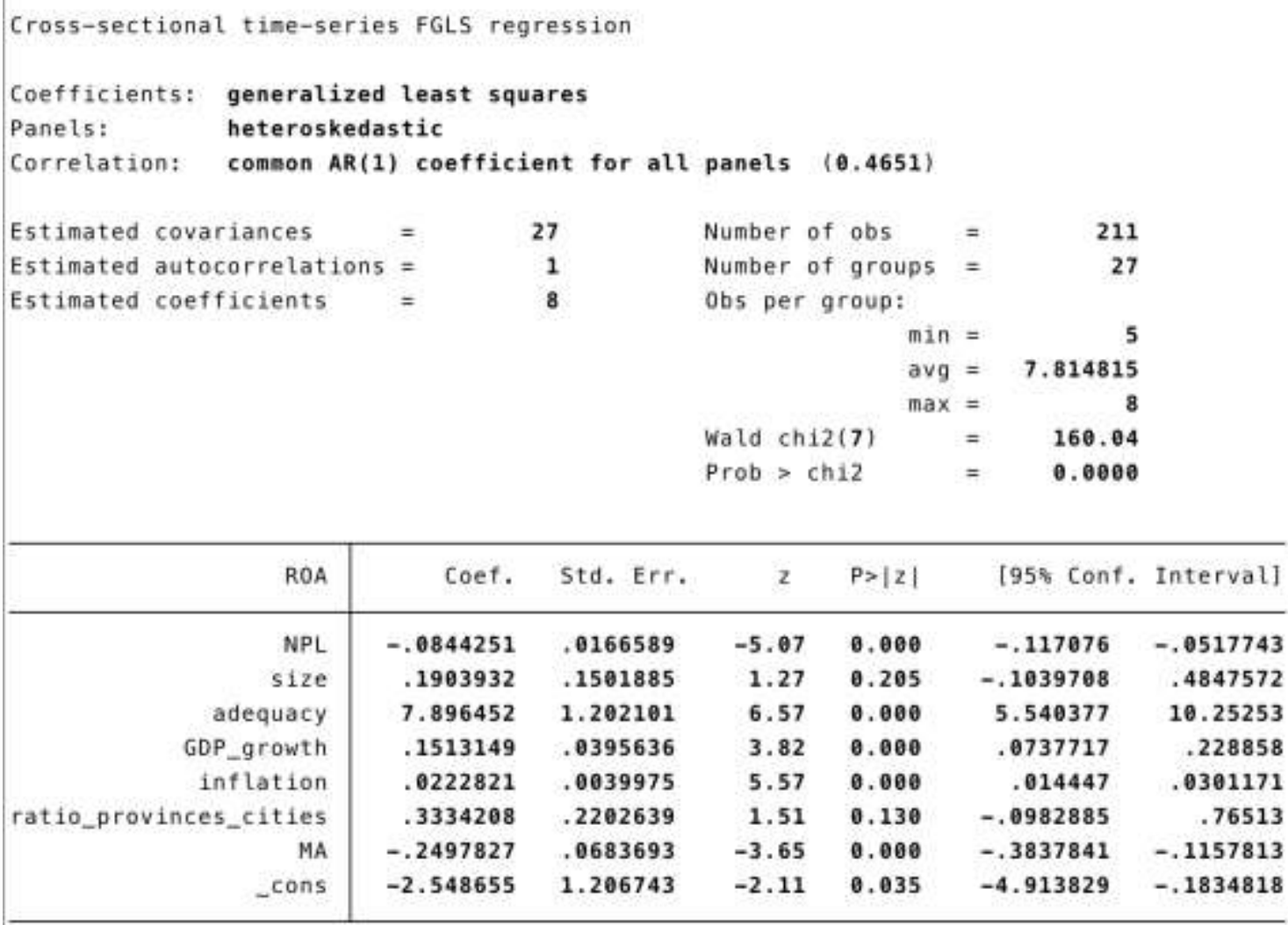

Figure 13: The Generalized Least Square

The $p$ value is 0.00 which is indicated that the model is desirable. 


\begin{tabular}{|c|c|c|c|c|}
\hline & (1) & (2) & (3) & (4) \\
\hline & ROA & ROA & ROA & ROA \\
\hline \multirow{2}{*}{ NPL } & $-0.0775 * * *$ & $-0.0707 * * *$ & $-0.0724 * * *$ & $-0.0844 * * *$ \\
\hline & {$[-3.27]$} & {$[-2.77]$} & {$[-3.03]$} & {$[-5.07]$} \\
\hline \multirow{2}{*}{ size } & 0.280 & $0.957 * * *$ & $0.575 * * *$ & 0.190 \\
\hline & {$[1.60]$} & {$[2.73]$} & {$[2.59]$} & {$[1.27]$} \\
\hline \multirow[t]{2}{*}{ adequacy } & $8.005 * * *$ & $10.73 * * *$ & $9.348 * * *$ & $7.896 * * *$ \\
\hline & {$[5.95]$} & {$[5.86]$} & {$[6.17]$} & {$[6.57]$} \\
\hline \multirow[t]{2}{*}{ GDP_growth } & $0.143 * *$ & $0.147 * *$ & $0.147 * *$ & $0.151 * * * *$ \\
\hline & {$[2.05]$} & {$[2.29]$} & {$[2.33]$} & {$[3.82]$} \\
\hline \multirow[t]{2}{*}{ inflation } & $0.0434 * * *$ & $0.0392 * * *$ & $0.0416 * * *$ & $0.0223 * * *$ \\
\hline & {$[6.11]$} & [5.59] & {$[6.47]$} & {$[5.57]$} \\
\hline \multirow[t]{2}{*}{ ratio_prov s } & 0.289 & $-1.167 * *$ & -0.203 & 0.333 \\
\hline & {$[1.11]$} & {$[-2,36]$} & {$[-0.60]$} & {$[1.51]$} \\
\hline \multirow[t]{2}{*}{ MA } & $-0.190 * *$ & $-0.325 *$ & $-0.278 * *$ & $-0.250 * * *$ \\
\hline & {$[-2,10]$} & {$[-1,91]$} & {$[-2,45]$} & {$[-3,65]$} \\
\hline \multirow[t]{2}{*}{ _cons } & $-3.370 * *$ & $-8.269 * * *$ & $-5.614 * * *$ & $-2.549 * *$ \\
\hline & {$[-2.28]$} & {$[-2.92]$} & {$[-3.11]$} & {$[-2.11]$} \\
\hline N & 211 & 211 & 211 & 211 \\
\hline$R-s q$ & 0.376 & 0.389 & & \\
\hline
\end{tabular}

$t$ statistics in brackets

* $\mathrm{p}<0.1, * * \mathrm{p}<0.05, * * * \mathrm{p}<0.01$

Figure 14: The table of the regression models

The list table of the OLS, fixed, random and Generalized least square indicated that the value of the Generalized least square is more desirable which is consistent with the supposed hypothesizes.

In the result of the regression model, there is the negative impact of the NPL and M\&A to the profit of the bank. Otherwise,the adequacy, GDP growth, inflation have the positive impact to the profit of the bank. There is no impact of the bank size and the province ratio on the profitability of the bank.

\section{Discussion:}

\section{The relationship of the profit and adequacy:}

The study also assumes that profit and adequacy are positive influences. Correlation coefficient is 7.893 shows that yield and capital ratios are supported relationship with the $p$ value is less than 0.01 . Therefore, it is known for the fact that the substantial relationship among the yield and capital ratios. Previous studies such as Saeed (2014); Broken (1995); DemirgucKunt and Huizinga (1999); Naceur and Omran (2011); Lee and Hsieh (2013) likewise show that the association between these two variables is proportional. As debated in the section of literature reviews above, the high capital-asset ratio leads to higher returns on non-interest traded funds that require lower interest rates. Specifically, banks with higher capital can reduce the risk of uninsured creditors paying bankruptcy costs in the event of bank failures, thereby reducing the interest rates required for unsecured debt. (Berge, 1995). In fact, out of the 28 commercial banks selected, banks with more favorable capital ratios 
will have the highest return on assets. For example, the highest ROA achieved by a bank over an eight-year period was Saigon Bank's $4.72 \%$, with its capital adequacy ratio of $21 \%$.

\section{The relationship of the NLP and profit:}

The study also assumes that profit and NPL are negative influence. Correlation coefficient is -0.0844 shows that yield and NPL are opposite relationship with the $p$ value is less than 0.01 . Therefore, there is the significant relationship among the yield and NPL. Previous studies such as Bessis, 2010, Duca and McLaughlin, 1990 and Miller and Noulas, 1997. Sufian and Chong, 2008 also show that the relationship between these two variables is opposite. As discussed in the literature review, the high bad debt ratio leads to low returns on non-interest traded funds that require higher interest rates. Specifically, banks with higher bad debt ratio can increase the risk of uninsured creditors paying bankruptcy costs in the event of bank failures, thereby rising the interest rates required for unsecured debt (Berge, 1995). In fact, out of the 28 commercial banks selected, banks with more favorable bad debt ratios will have the highest return on assets.

\section{The relationship of M\&A and profit:}

The study also assumes that profit and M\&A are negative influence. Correlation coefficient is -0.25 shows that yield and M\&Aare negative relationship with the $p$ value is less than 0.01 . Therefore, there is the significant relationship among the yield and M\&A. Previous studies such as Ali et al. (2012). Ali et al., 2012 also show that the relationship between these two variables is negatively supported. As discussed in the literature review, the high M\&A leads to low profit of the bank due to the high operation cost. Besides, the bank must suffer the high bad debt ratio when merging with the merged banks.

\section{The relationship of the inflation rate and the profit:}

Regarding to the hypothesis is established in the study, there is a supportive relationship between the inflation rate and profitability of the bank. However, the hypothesis was substantiated by regression results. At $99 \%$, the bank size does have a positively significant impact on profitability since the correlation coefficient is 0.0223 . Economically, the inflation is the rise of the price of the goods and products of the entire economic in the certain period which is typically a month or a year (Arnold, 2013). Revell (1979) argued that the inflation is the important factor in the research of the bank profit. The participation of the inflation will result in the accurate estimation. The inflation rate is the base for the bank determine the interest of the loan offered to the customers. Thus, the relation among profitability and inflation is hard to predict (Perry, 1992). More specifically, predictable inflation can contribute to quicker rates of variation than inflation costs, which can be considered as being more rewarding. Besides, when there is the full prediction of the inflation, the profit of the bank will increase in the slower way when comparing to the increasing of the cost. The reason is absence of the regulation of the bank interest rate. This leads to the negative relation of profit margin and a rate of inflation Chong, 2008), (Molyneux and Thornton, 1992, Tan and Floros, 2012, Sastrosuwito and Suzuki, 2012). In contrast, Naceur and Kandil (2009) and Saeed (2013) argued that inflation rates and bank performance were contrariwise comparative. It can be clarified that there is the unsupportive relation among the inflation and the performance of the bank. The reason is the high inflation rate will increase the interest of the bank loan. The growth of the loan price will reduce the demand of the loan. Therefore, the profit of the bank will be reduced (Naceur and Kandil, 2009). In the case of the research, there is positive relationship among the inflation rate and the profit of the bank. It is indicated that the inflation rate will increase the interest rate of the bank which will increase the profit of the bank.

\section{The relationship of the GDP and the profit:}

Basing on the result of the model, there is the positiverelationship among the GDP growth and the profitability of the bank. The result of the model is consistent with the research of Athanasoglou and the research team, 2006. In the research of Athanasoglou and the research team, they argue that the change in GDP per capita has had a significant impact on bank profitability. The high GDP growth will result in the high profitability because 
the bank provides the high loans for the enterprises. Therefore, the enterprises will create more profit to contribute to the development of the economics. The more loans are made, the more profit the bank will create.

\section{The relationship of the province ratio and the profit:}

There has not been any indications for the banks over the relationship between the province ratio as well as the profit. These ratio reflected on the development and growth of the operations (Marta et al., 2015). The bank holding the better divisions in respect to provinces also specified the better based for growing of the business. In accordance to the business operation, it has acknowledged for the desire customers for the operations and establishments in branches. In this sense of more province ratio, the result will come with an upsurge of the loan providing by the financial institution resulting in a greater profit for the business (Marta et al., 2015). Though, in term of the increase of the province ration, the related costs will occurred more for the business (Adel et al., 2007). The benefit of the increasing of the market shares will be offset by the increasing of operating cost. For this reason, it can be concluded that there is no impacts on the profit of the business.

\section{The relationship of the bank size and the bank profit.}

There is no impact of the bank size to the bank profit. It is supposed large bank will benefit for the large market shares. Otherwise, the bank will spend much operating cost to run the bank. Therefore, the benefit of the large market shares will be offset by the high operating cost. Therefore, there is no change in the profit of the bank (Marta et al., 2015). The result of the bank size impacting on the bank profit is consistent with the result of province ratio influencing on the bank profit. Normally, the large bank will have more chance to connect with the wide large of the customers which have the system covering across Vietnam province such BIDV, Vietin Bank, Vietcom bank...Therefore, these bank will suffer the high operating cost. Otherwise, the small bank such as Tien Phong possesses the limited branches. Therefore, the operating cost will be saved (Adel et al., 2007).

\section{Main Text (Review only)}

This section may be divided into subsections or may be combined.

\section{Conclusions}

It is tremendously significant for executives and other stakeholders including the banks' partners, employees, government and financial institutions, to comprehend the issues and aspects which can have influences on bank profits. Identifying these features supports regulators and bank executives improve policies to upsurge bank profitability in the future. This study purposes to scrutinize the elements of bank profitability in the Vietnamese banking sector in order to deliver information to investors and regulators. Examination of the balance sheet data for the period 2010 to 2017, comprising an impression of the Vietnamese banking industry, evocative statistics, correlational correlation between explanatory variables and finally differential modelling regression.

The results show that the banking sector in Vietnam is highly concentrated as the majority of market share of outstanding loans and credit is owned by the four leading state banks namely Agribank, Bank of Agriculture and Rural Development Vietnam Joint Stock Commercial Bank for Industry and Trade (Vietinbank) and Bank for Investment and Development of Vietnam (BIDV) although there are signs that commercial banks and Foreigners banks have begun to seize market share from State Banks in both the borrowing and lending markets. In addition, the assets and capital of domestic banks have improved considerably during the study period. However, profits have declined significantly from 2011 to 2013, mainly due to bad debt ratio increased, from 2. $2 \%$ in 2011 to $4.67 \%$ in 2013. In addition, bad debt and bad debt provisions in Vietnam are underestimated due to the discrepancy between Vietnam Accounting Standards (" VAS) and International Financial Standard (IFRS). The research is provided the result is as expected and consistent with Vietnamese conditions. 
The study conducted a regression model to examine the linkage between the dependent variable on the return on assets and six other explanatory variables: bank size, capital structure, NPL, asset turnover, inflation rate and GDP. The results show that capital structure and size are proportional to bank profitability. GDP growth do not have theimpact on the profitability. Accordingly, larger-capitalized banks may reduce the likelihood that creditors of uninsured debt will pay bankruptcy costs in the event of bank losses, thereby lowering interest rates that homeowners. This debt is set aside for uninsured debt (Berge, 1995). Besides, benefits Leverage generated from a low risk account (such as government securities) is lower than the return on a less moving account with higher risk (eg loans to household family and organization). As the moment, advanced levels of equity imitate a lower level of liquidity risk that can later cause lower returns. On the other hand, it seems that the profitability of public sector banks is generally lower than that of private banks. This conclusion is reliable with previous theories. However, the results of the regression model show that there is no basis for agreeing with the hypothesis on the relationship between bank profit and credit risk, bank size and inflation. In fact, the banking sector in Vietnam does not support these hypotheses and in fact there are opposing views about hypotheses. This is because Vietnam's banking industry has just moved from a single-tier banking structure to two-tier banking for more than 20 years and market performance may not be fully fulfilled. Principles or assumptions that work well in international markets. For the conclusion, the research has been able to address two inquiries: What are the factors contributing to profitability of banking in Vietnam and how these features influence the profitability of banks?

\section{Data Availability (excluding Review articles)}

This section should describe how readers may access the data underlying the findings of the study.

\section{Conflicts of Interest}

There is no interest conflict

\section{Funding Statement}

Authors should state how the research described in their article was funded, including grant numbers if applicable.

\section{Acknowledgments}

All acknowledgments (if any) should be included at the very end of the manuscript before the references. Anyone who made a contribution to the research or manuscript, but who is not a listed author, should be acknowledged (with their permission).

\section{References}

1. Ali A, Ali SA,. (2012). Working Capital Management: Is It Really Affects the Profitability? Evidence from Pakistan. Global Journal of Management and Business Research 12 (17), 74-78.

2. Annual Review 2007. (2007). ACCA.

3. Akbas, H.E., 2012. Determinants of Bank Profitability: An Investigation on Turkish Banking Sector. In: Öneri Dergisi 10 (37), 103-110.

4. Alexiou, C., Sofoklis, V., 2009. Determinants of bank profitability: Evidence from the Greek banking sector. In: Ekonomski anali 54 (182), 93- 118.

5. Alper, D., Anbar, A., 2011. Bank specific and macroeconomic determinants of commercial bank profitability: empirical evidence from Turkey. Business and Economics Research Journal 2(2), 139-152. 
6. Andrieb, A. M., Cocris, V., 2010. A Comparative Analysis of the Efficiency of Romanian Banks, Romanian Journal of Economic Forecasting 13, 54-75.

7. Athanasoglou, P.P., Delis, M.D., Staikouras, C.K., 2006. Determinants of Bank Profitability in the South Eastern European Region, Bank of Greece, Working Paper No. 47.

8. Athanasoglou, P. P., Brissimis, S. N., and Delis, M. D. (2008). Bank-specific, industry-specific and macroeconomic determinants of bank profitability. Journal of International Financial Markets, Institutions and Money, 18:121-136.

9. Badola, B.S., Verma, R., 2006. Determinants of Profitability of Banks in India: A Multivariate Analysis. Delhi Business Review 7(2), 79-88.

10. Berger, A.N., 1995. The Relationship between Capital and Earnings in Banking. Journal of Money, Credit and Banking 27(2), 432-456.

11. Bessis, J. 2010. Risk management in banking. 3rd ed. United Kingdom: John Wiley.

12. Bodie, Z., Kane, A., \& Marcus, A. J. (2005). Investments. 6. p.

13. BOYD, J. H., \& DE NICOLÓ, G. (2005). The Theory of Bank Risk Taking and Competition

14. Revisited. The Journal of Finance, 60(3), 1329-1343.

15. Cooper, L. P. (2003), "A research agenda to reduce risk in new product development through knowledge management : a practitioner perspective", Journal of Engineering and Technology Management, Vol. 20 No. 1, pp. 117-140.

16. De Nicolo, Gianni, Philip Bartholomew, Jahanara Zaman, and Mary Zephirin, 2004, Bank consol- ' idation, conglomeration and internationalization: Trends and implications for financial risk, Financial Markets, Institutions and Instruments 13, 173-217.

17. Dick, Astrid, 2006, Nationwide branching and its impact on market structure, quality and bank performance, Journal of Business 79, forthcoming

18. Demirgüç-Kunt, A., \& Huizinga, H. (1999). Determinants of commercial bank interest margins and profitability: some international evidence. The World Bank Economic Review, 13(2), 379-408.

19. Duca, J., \& McLaughlin, M. (1990). Developments affecting the profitability of commercial banks. Federal Reserve Bulletin, 76(7), 477-499.

20. Hellmann, Thomas, Kevin Murdock, and Joseph Stiglitz, 2000, Liberalization, moral hazard in banking, and prudential regulation: Are capital requirements enough? American Economic Review 90, 147-165.

21. Hoa, D. T., \& Lin, J. Y. (2014). Provincial Governance and Foreign Direct Investment in Vietnam: An empirical study at sub nation level. International Journal Of Humanities And Applied Social Science, 1(2).

22. Khrawish, H. A., \& Al-Sa'di, N. M. (2011). The impact of e-banking on bank profitability: Evidence from Jordan. Middle Eastern Finance and Economics, 13, 142-158.

23. Miller, Stephen, and Athanasios Noulas. 1997. Portfolio Mix and Large-Bank Profitability in the USA. Applied Economics 29: 505-512. 
24. Ntuite, S. R. (2015). Analysis of Financial Performance of Commercial Banks in Rwanda.

25. Petria, N., Capraru, B., \&lhnatov, I. (2015). Determinants of banks' profitability: evidence from EU 27 banking systems. Procedia Economics and Finance, 20, 518-524.

26. Petersen, Mitchell, and Raghu Rajan, 1995, The effect of credit market competition on lending relationships, Quarterly Journal of Economics 110, 407-443.

27. Padoa-Schioppa, Tommaso, 2001, Bank competition: A changing paradigm, European Finance Review 5, 13-20.

28. Perry, P. (1992). Do Banks Gain or Lose from Inflation. Journal of Retail Banking, 14 (2), 25-30.

29. Rasiah, D., Tong, D.Y.K. and Kim, P.K., 2014. Profitability and firm size-growth relationship in construction companies in Malaysia from 2003 to 2010. Review of Pacific Basin Financial Markets and Policies, 17(03), p.1450014.

30. Repullo, Raphael, 2003, Capital requirements, market power, and risk-taking in banking, Discussion paper no. 3721, CEPR.

31. Revell, J., 1979. Inflation and financial institutions. London: The Financial Times Ltd.

32. Yang, F. J., Lin, C. W., \& Chang, Y. N. (2010). The linkage between corporate social performance and corporate financial performance. African Journal of Business Management, 4(4), 406-413.

33. Athanasoglou, P., Delis, M., \&Staikouras, C. (2006). Determinants of bank profitability in the South Eastern European region.

34. Kosmidou, K. (2008). The determinants of banks' profits in Greece during the period of EU financial integration. Managerial Finance, 34(3), 146-159.

35. Hassan, M. K., \& Bashir, A. H. M. (2003, December). Determinants of Islamic banking profitability. In 10th ERF annual conference, Morocco (Vol. 7).

36. Petria, N., Capraru, B., \&lhnatov, I. (2015). Determinants of banks' profitability: evidence from EU 27 banking systems. Procedia Economics and Finance, 20, 518-524.

37. Staikouras, C. K., \& Wood, G. E. (2004). The determinants of European bank profitability. International business and economics research journal, 3, 57-68.

38. Sheytanova, T. (2015). The Accuracy of the Hausman Test in Panel Data: a Monte Carlo Study.

39. Sufian, F. and Chong, R.R. (2008). Determinants of bank profitability in a developing economy: empirical evidence from Philippines. Asian Academy of Management Journal of Accounting and Finance, 4(2), 91112.

40. Beresford, M. (2008). DoiMoi in review: The challenges of building market socialism in

41. Vietnam. Journal of Contemporary Asia, 38(2), 221-243.

42. Obamuyi(2013), "Detarminants of banks'profitability in a developing economy: Evidence from Nigeria", Organizations and markets in emerging economies, 2013, VOL. 4, No. 2(8), Pp97-112. 
Preparation of Figures

\begin{tabular}{r|rrrrr} 
Variable & Obs & Mean & Std. Dev. & Min & Max \\
\hline ROA & 224 & .7324049 & .6113092 & .0070912 & 4.728902 \\
NPL & 224 & 2.43158 & 1.513058 & .21 & 10.03 \\
size & 224 & 7.976311 & .5108421 & 6.317711 & 9.080007 \\
adequacy & 224 & .1130766 & .2614364 & .0349757 & 3.957735 \\
GDP_growth & 224 & 6.127068 & .522058 & 5.247367 & 6.81 \\
\hline inflation & 224 & 7.057507 & 5.103882 & .8786037 & 18.67748 \\
ratio_prov S & 211 & .5247875 & .2527517 & .1111111 & 1 \\
MA & 224 & .1785714 & .3838508 & 0 & 1
\end{tabular}

The descriptive table of the variables

\begin{tabular}{r|rrrrrrrr} 
& ROA & NPL & Size adequacy & GDP_gr inflat n ratio_ S & MA \\
\hline ROA & 1.0000 & & & & & & & \\
NPL & -0.1991 & 1.0000 & & & & & & \\
Size & -0.1365 & -0.0540 & 1.0000 & & & & & \\
adequacy & 0.3703 & 0.0463 & -0.7448 & 1.0000 & & & & \\
GDP_growth & 0.0159 & -0.2877 & 0.1158 & -0.1726 & 1.0000 & & & \\
inflation & 0.3862 & 0.0915 & -0.1848 & 0.1987 & -0.2572 & 1.0000 & & \\
ratio_prov 5 & -0.0007 & -0.0218 & 0.8372 & -0.4945 & 0.0535 & -0.1058 & 1.0000 & \\
MA & -0.2404 & 0.1161 & 0.2091 & -0.1984 & 0.0907 & -0.1914 & 0.1688 & 1.0000
\end{tabular}

The correlation table among the variables

\begin{tabular}{|c|c|c|c|c|c|c|}
\hline Source & S5 & $d f$ & MS & Number of obs & $=$ & 211 \\
\hline Model & 28.9018585 & 7 & 4.12883693 & Prob > F & $=$ & 0.0000 \\
\hline Residual & 48.0603649 & 203 & .236750566 & $R$-squared & $=$ & 0.3755 \\
\hline Total & 76.9622234 & 210 & .366486778 & $\begin{array}{l}\text { Ad] R-squared } \\
\text { Root MSE }\end{array}$ & $\begin{array}{l}= \\
=\end{array}$ & $\begin{array}{l}0.3540 \\
.48657\end{array}$ \\
\hline
\end{tabular}

\begin{tabular}{r|rrrrrr}
\hline ROA & Coef. & Std. Err. & $t$ & P $>|t|$ & [95\% Conf. Interval] \\
\hline NPL & -.0774659 & .0236815 & -3.27 & 0.001 & -.1241592 & -.0307726 \\
size & .2804091 & .1749777 & 1.60 & 0.111 & -.0645977 & .6254159 \\
adequacy & $\mathbf{8 . 0 0 5 2 5 6}$ & 1.344477 & 5.95 & 0.000 & 5.354326 & 10.65619 \\
GDP_growth & .1431845 & .0697568 & 2.05 & 0.041 & .0056438 & .2807252 \\
inflation & .04343 & .0071026 & 6.11 & 0.000 & .0294258 & .0574343 \\
ratio_provinces_cities & .2892127 & .2604341 & 1.11 & 0.268 & -.2242901 & .8027156 \\
MA & -.1902996 & .0907077 & -2.10 & 0.037 & -.3691497 & -.0114495 \\
_cons & -3.369974 & 1.476086 & -2.28 & 0.023 & -6.280401 & -.4595469 \\
\hline
\end{tabular}


The linear regression model

\begin{tabular}{|c|c|c|}
\hline variable & VIF & 1 /VIF \\
\hline $\begin{array}{r}\text { size } \\
\text { ratiofprov s } \\
\text { adequacy } \\
\text { GDP.growth } \\
\text { intiation } \\
\text { NPL } \\
\text { MA }\end{array}$ & $\begin{array}{l}6.55 \\
3.84 \\
2.61 \\
1.18 \\
1.13 \\
1.12 \\
1.16\end{array}$ & $\begin{array}{l}0.152565 \\
0.260188 \\
0.382776 \\
0.844221 \\
0.882671 \\
0.891692 \\
0.905696\end{array}$ \\
\hline Mean VIf & 2.51 & \\
\hline
\end{tabular}

The collinearity result of the variables

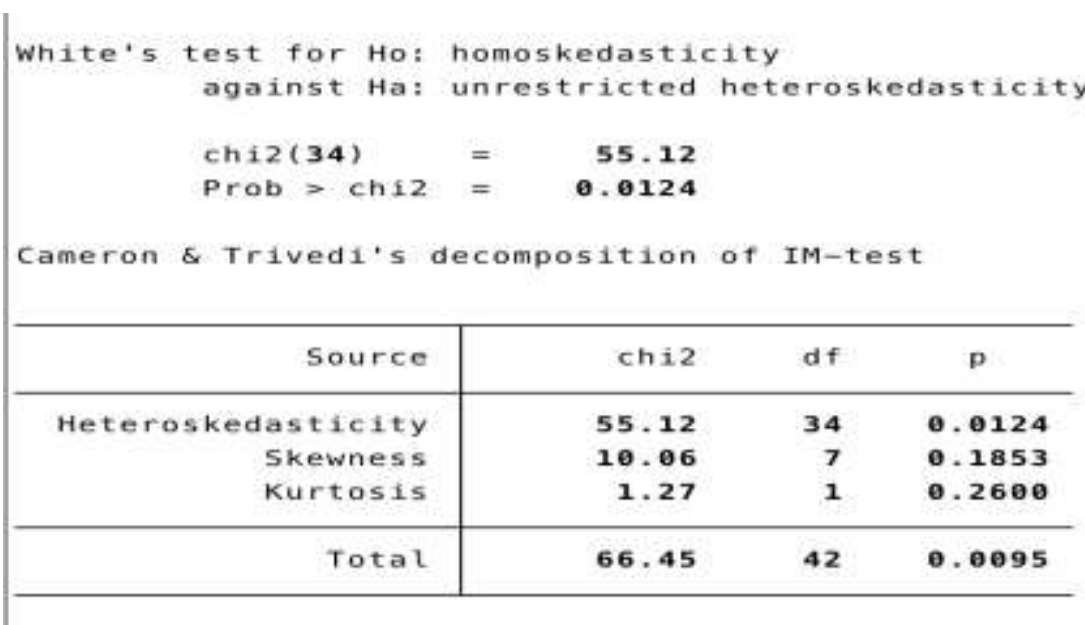

The homoscedasticity test

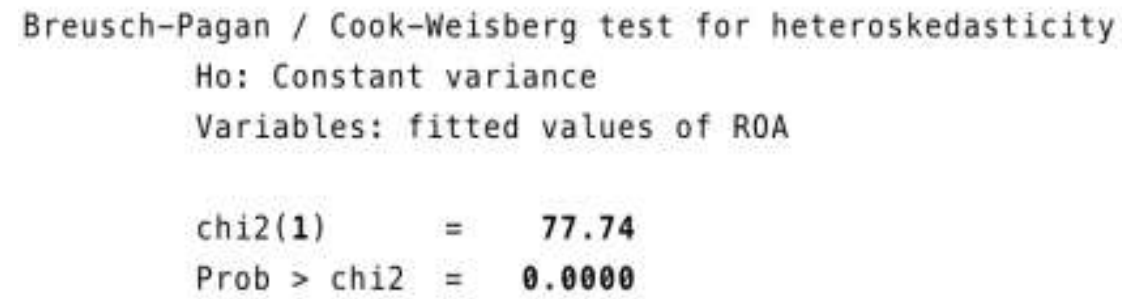

the Breusch - Pagan test

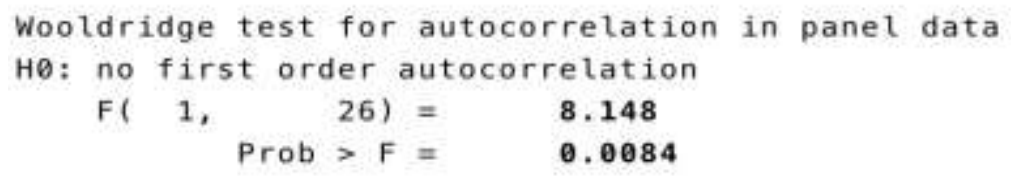

The Wooldridge test 


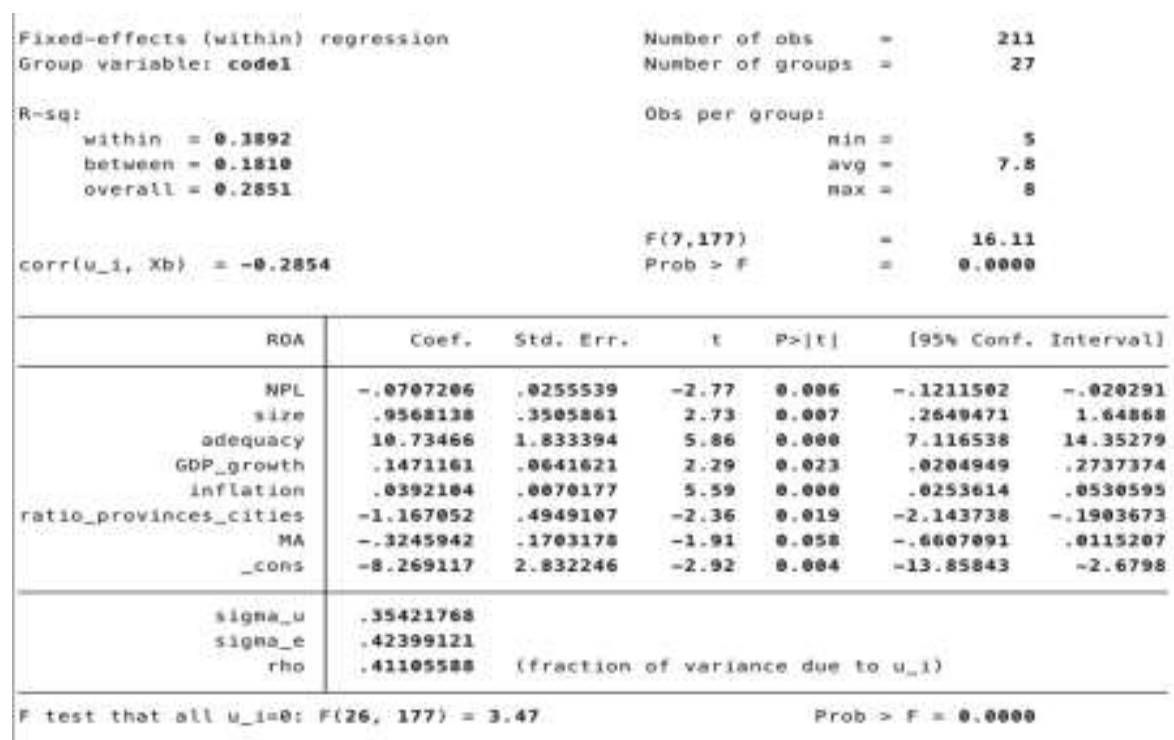

The fixed effect model result

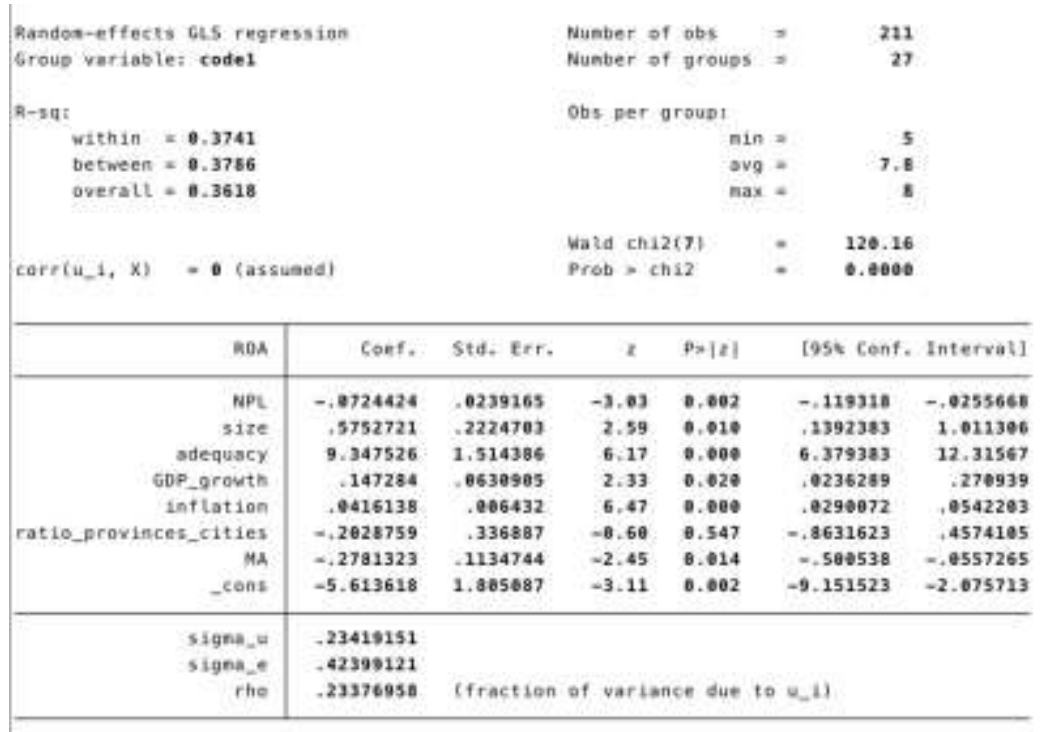

The random effect model result 


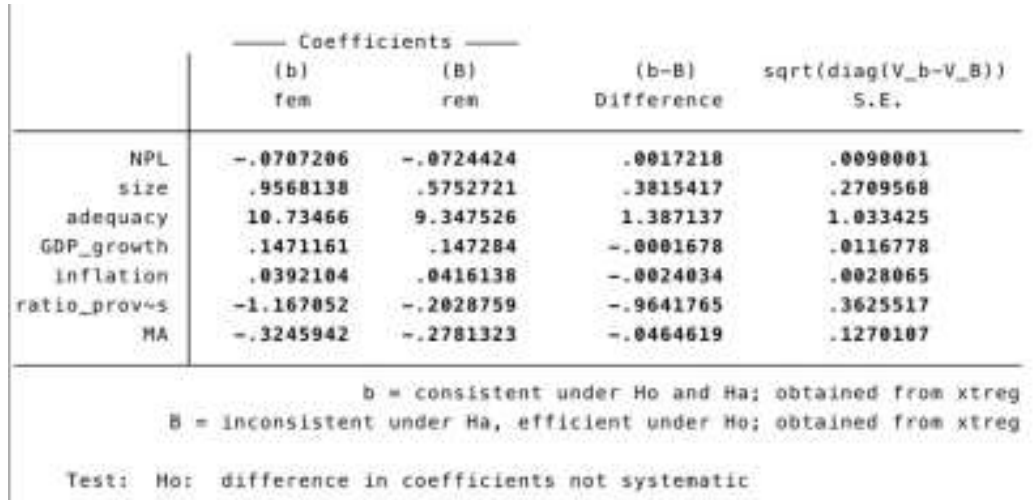

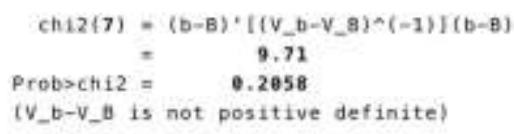

The Hausman test

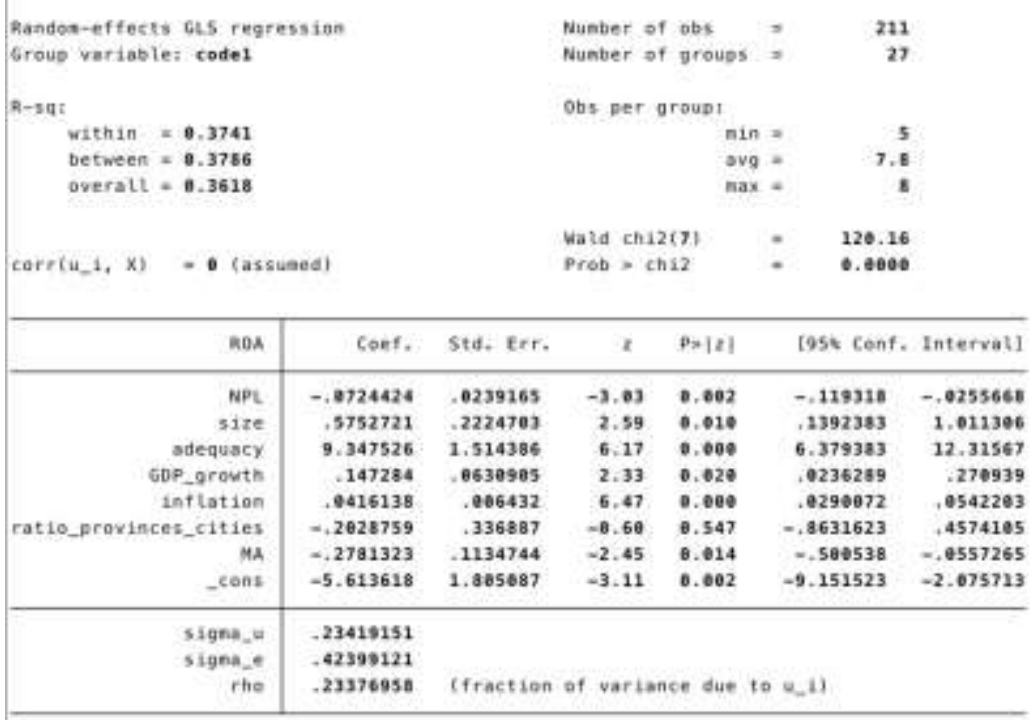

The random effect model result

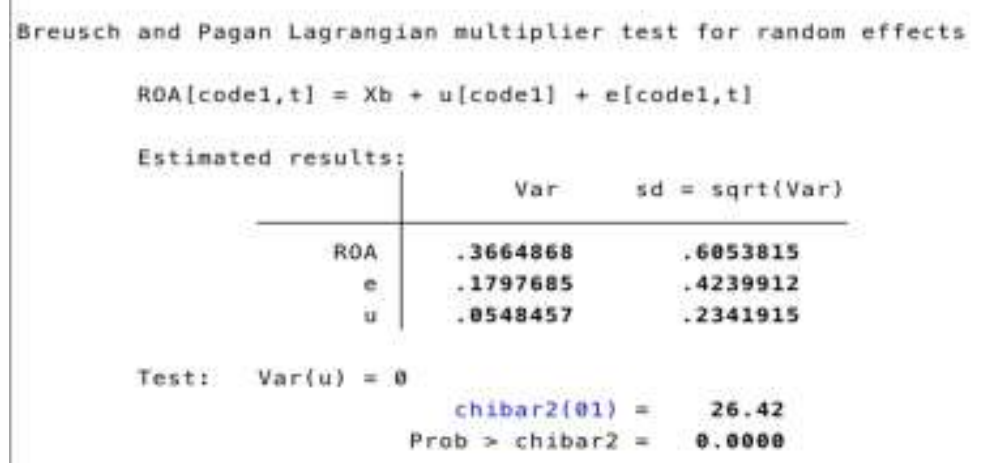

The Breusch and Pagan test result 
Levin-Lin-Chu unit-root test for ROA

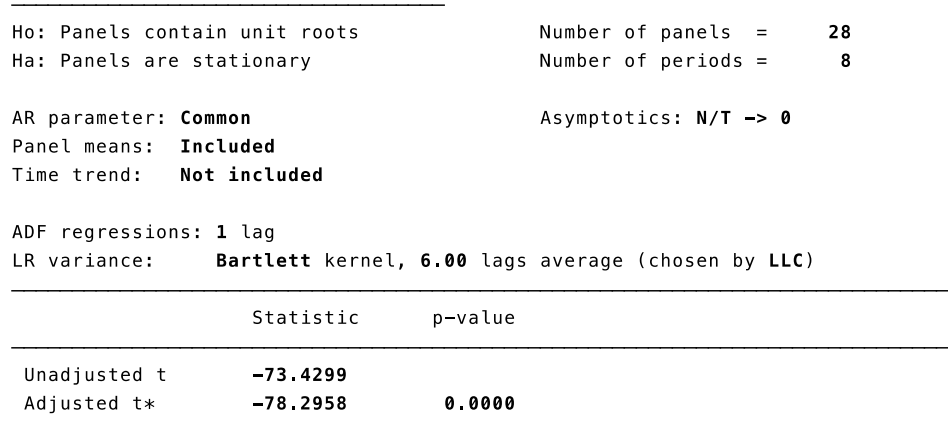

The result of unit root test

Hadri LM test for ROA

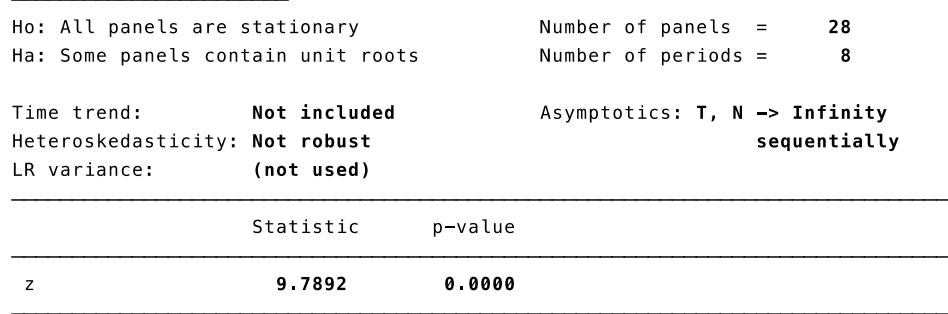

The result of stationary test

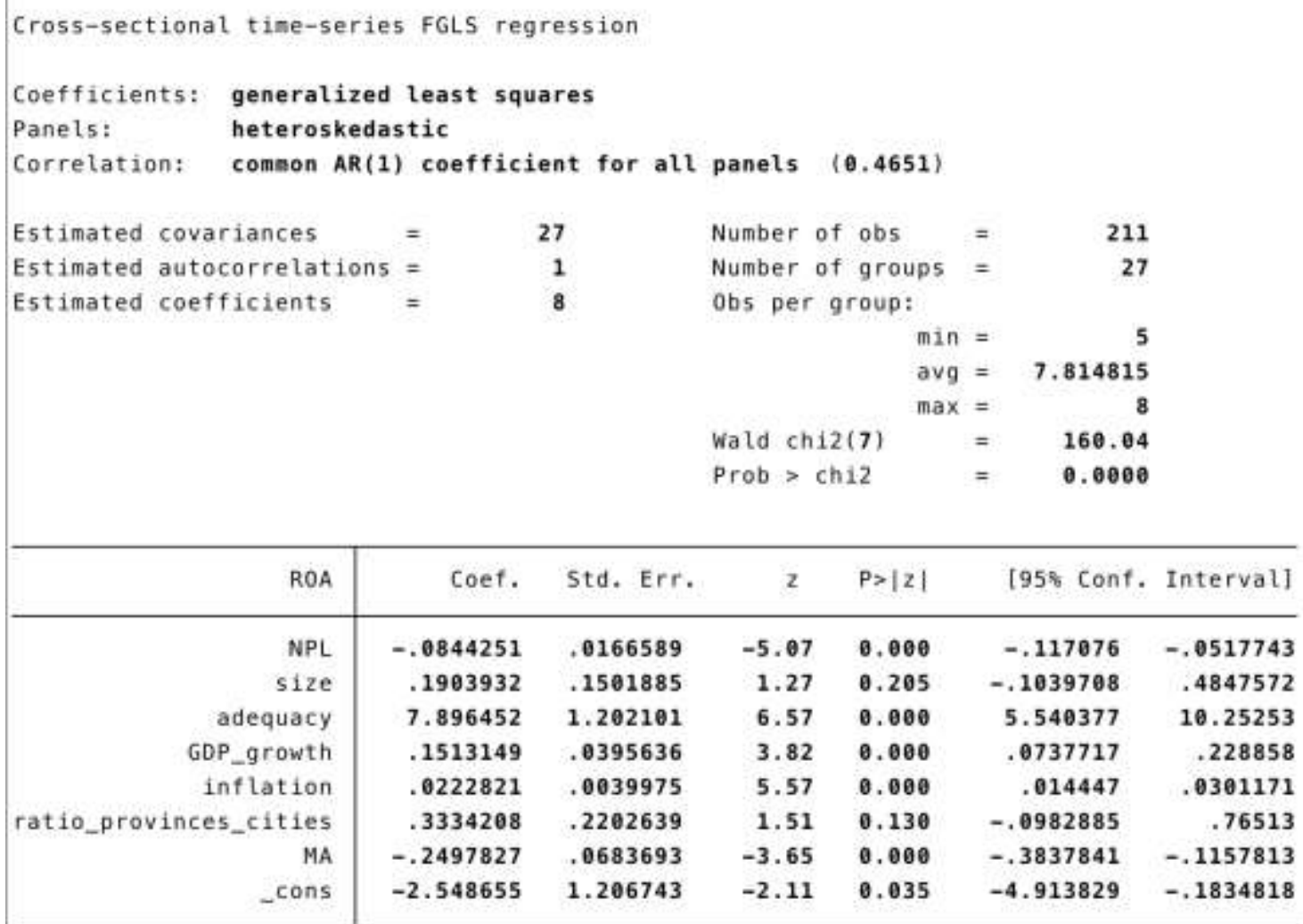

The Generalized Least Square 


\begin{tabular}{|c|c|c|c|c|}
\hline & (1) & (2) & (3) & (4) \\
\hline & ROA & ROA & ROA & ROA \\
\hline \multirow[t]{2}{*}{ NPL } & $-0.0775 * * *$ & $-0.0707 * * *$ & $-0.0724 * * *$ & $-0.0844 * * *$ \\
\hline & {$[-3.27]$} & {$[-2.77]$} & {$[-3.03]$} & {$[-5.07]$} \\
\hline \multirow[t]{2}{*}{ size } & 0.280 & $0.957 * * *$ & $0.575 * * *$ & 0.190 \\
\hline & {$[1.60]$} & {$[2.73]$} & {$[2.59]$} & {$[1.27]$} \\
\hline \multirow[t]{2}{*}{ adequacy } & $8.005 * * *$ & $10.73 * * *$ & $9.348 * * *$ & $7.896 * * *$ \\
\hline & [5.95] & {$[5.86]$} & {$[6.17]$} & {$[6.57]$} \\
\hline \multirow[t]{2}{*}{ GDP_growth } & $0.143 * *$ & $0.147 * *$ & $0.147 * *$ & $0.151 * * * *$ \\
\hline & {$[2.05]$} & {$[2.29]$} & {$[2.33]$} & {$[3.82]$} \\
\hline \multirow[t]{2}{*}{ inflation } & $0.0434 * * *$ & $0.0392 * * *$ & $0.0416 * * *$ & $0.0223 * * *$ \\
\hline & {$[6.11]$} & {$[5.59]$} & {$[6.47]$} & {$[5.57]$} \\
\hline \multirow[t]{2}{*}{ ratio_prov s } & 0.289 & $-1.167 * *$ & -0.203 & 0.333 \\
\hline & {$[1.11]$} & {$[-2,36]$} & {$[-0.60]$} & {$[1.51]$} \\
\hline \multirow[t]{2}{*}{ MA } & $-0.190 * *$ & $-0.325 *$ & $-0.278 * *$ & $-0.250 * * *$ \\
\hline & {$[-2,10]$} & {$[-1.91]$} & {$[-2,45]$} & {$[-3.65]$} \\
\hline \multirow[t]{2}{*}{ - cons } & $-3.370 * *$ & $-8.269 * * *$ & $-5.614 * * *$ & $-2.549 * *$ \\
\hline & {$[-2.28]$} & {$[-2.92]$} & {$[-3.11]$} & {$[-2.11]$} \\
\hline N & 211 & 211 & 211 & 211 \\
\hline$R-s q$ & 0.376 & 0.389 & & \\
\hline
\end{tabular}

$t$ statistics in brackets

* $\mathrm{p}<0.1$, ** $\mathrm{p}<0.05, * * * \mathrm{p}<0.01$

The table of the regression models

\section{Preparation of Tables}

Tables should be cited consecutively in the text. Every table must have a descriptive title and if numerical measurements are given, the units should be included in the column heading. Vertical rules should not be used.

\section{Supplementary Materials}

Supplementary materials are the additional parts to a manuscript, such as audio files, video clips, or datasets that might be of interest to readers. Authors can submit one file of supplementary material along with their manuscript through the Manuscript Tracking System. If there is more than one file, they can be uploaded as a .ZIP file.

A section titled "Supplementary Material" should be included before the references list with a concise description for each supplementary material file. Supplementary materials are not modified by our production team. Authors are responsible for providing the final supplementary materials files that will be published along with the article.

\section{Proofs}

Corrected proofs must be returned to the publisher within two to three days of receipt. The publisher will do everything possible to ensure prompt publication. 


\section{How to format your article:}

Select all Text with ctrl+ A and apply these settings

- $\quad$ Font Size: 10

- $\quad$ Font: segoe UI

\begin{tabular}{|l|l|l|l}
\hline Segoe UI & -10 & $\mathrm{~A}^{\wedge}$
\end{tabular}

Page Size: $\mathrm{A}_{4}$

Margins: Moderate

- Top: $1^{\prime \prime}$ Bottom: $1^{\prime \prime}$

- Left:0.75" Right: $0.75^{\prime \prime}$

Paragraph:

Indentation

- Left: 0"

- Right: 0" Special:First line BY:0"

Spacing

- $\quad$ Before: $0 \mathrm{pt}$

- $\quad$ After: 0 pt Line Spacing: single

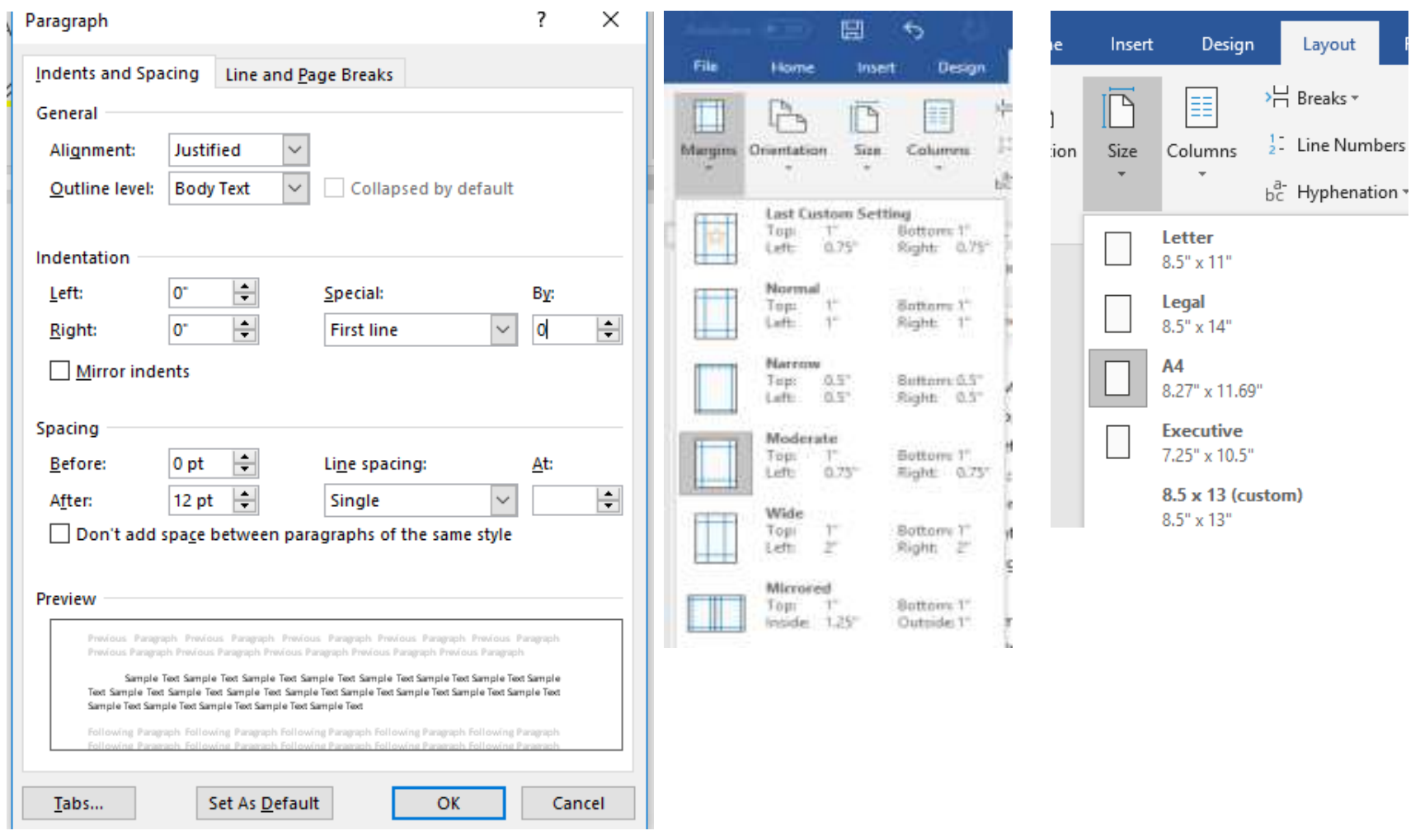

